\title{
RURAL TOURISM IN SERBIA IN THE AGE OF THE CORONAVIRUS EPIDEMIC
}

\author{
Pavle Radanov ${ }^{1}$ \\ Ivana Lešević ${ }^{2}$
}

DOI: https://doi.org/10.31410/tmt.2020.393

\begin{abstract}
The coronavirus pandemic has caused a change of tourist habits, including turning more to domestic destinations. Serbian travel culture is specific, because most travelers choose sea destinations, given that Serbia is a continental country. Considering the number of natural resources along with accommodation capacities, it is necessary to work more on the promotion of rural tourism, in order to change the awareness and habits of travelers. The research conducted for this purpose addressed the travel habits of domestic tourists in their own country and showed that there are great opportunities in this regard to increase the number of guests in rural tourism, which will become permanent and use other benefits a rural household can provide. It also represents the opportunity to revitalize abandoned and devastated areas and affects the economic well-being of the whole region and even the whole country.
\end{abstract}

Keywords: Serbia, Travel, Accommodation, Local authorities, Tourist organizations.

\section{INTRODUCTION}

$\mathrm{M}$ odern age and modern economy, despite all technical and technological achievements, are not immune to natural forces and laws, as shown by the coronavirus pandemic that struck the world in late 2019 and early 2020 and which still cannot see the end, nor consequences. Even the most developed countries in the world, with the most stable economies, are exposed to the large losses, due to disabled work processes, redirected budget toward the fight against virus and social expenditures to help people get through this period more easily. For small and medium-sized economies, this wave has been disastrous, and losses are now being calculated, as well as ways to rebuild their financial resources.

There is practically no industry that was not endangered during the state of emergency in Serbia, and the biggest losses were certainly suffered by the tourism and catering sector because travel is limited and there are no indications when the situation will return to the level before the pandemic. "Tourism, as a social and economic phenomenon, is a business activity the most directly exposed to constant and strong changes" (Čerović, 2002, p. 21). "With its important features and the ways of functioning, the tourist market differs from other markets for goods and services" (Spasić, 2013, p. 16). Planning a trip abroad is uncertain and associated with many aggravating circumstances, which include mandatory testing for Covid-19, quarantine, or self-isolation, which again does not guarantee that the planned trip will be realized because experience shows that the epidemiological situation can change drastically in just a few days and with it the rules for entering certain countries from Serbia. "It is expected that in such conditions, tourism will suffer the greatest crisis when we talk about the economy. In a situation where humanity is struggling to survive, travel is not a priority" (Brzaković et al., 2020, p.104). In such conditions, it is safest to turn to domestic resources, to travel, relax and entertain in your country,

\footnotetext{
$1 \quad$ Faculty of Applied Management, Economy and Finance, Jevrejska 24/1, Belgrade, Serbia
}

2 Faculty of Applied Management, Economy and Finance, Jevrejska 24/1, Belgrade, Serbia 
and Serbia certainly has a large tourist offer that is unfairly neglected by domestic travelers, so this could be an opportunity to change the situation. It also should be noted that "there are other diseases, which may not deserve global attention, but which can be transmitted through the interaction of people from different communities. Although they are not fatal to health, such diseases can cause sociological and economic stress among the domicile population, which may have weaker immune resistance to certain diseases than the tourist population" (Tomka, 2012, p. 36). It is doubly important to promote the potentials of domestic tourism, firstly to encourage the population not to leave the country in uncertain epidemiological conditions, and secondly to pour financial resources into the domestic budget, which will significantly contribute to the recovery of this economic sector. Serbia is a rural country: "According to the definition of the Organization of Economic Cooperation and Development (OECD) rural regions in Serbia cover up to $85 \%$ of the total territory (population density is below 150 inhabitants per $\mathrm{km} 2$ ), in which lives more than a half of the total population of Serbia (55\%)" (Medojević et al., 2011, p. 93). "However, the average capacity occupancy in rural tourism in Serbia is only 4\% (Program for the development of sustainable rural tourism in the Republic of Serbia, 2011), and the average capacity occupancy in rural tourism in the European Union is 25\% (Bartlet, 2006)" (Radović, 2020, p.1338). From the very beginning of the epidemic and especially in the last period it is noticeable the effort to promote domestic destinations, spas, and mountains, as well as rural and other types of tourism. There are numerous TV shows and newspaper reports about mountains, rivers, spas in Serbia, with an emphasis on the peculiarities and rarities that the nature of this country provides, in order to attract domestic tourists to visit destinations in Serbia with an attractive offer. Knowing what kind of tourist resources Serbia has, this position is completely justified, and it can be noticed that one negative situation had a positive consequence in drawing attention to the cultural, natural, and historical sights of our country. It had to be noticed that "mass communication is the most common form of communication in the modern world. It takes place precisely through the media and it is the one that creates public opinion" (Lešević et al. 2020, p. 525). The government can easily use public media to make an influence on the domestic tourists because the "public media as a mediating instance between society and the state, enables the education of the public that becomes the bearer of public opinion" (Tomić, 2003, p. 120). That is why we have to be aware that "successful development of rural tourism requires designed marketing with special arrangements for tourists to stay in rural areas, as well as to make their experience exciting and, in general, let them feel values of the rural lifestyle in the ecologically healthy countryside" (Đorđević, 2016, p.43).

"For years, tourism has been a significant factor of social and economic development of Serbia. Tourism affects the development of numerous economic and non-economic activities, and conditions development of the hotel industry as one of the leading economic activities. Tourists increasingly have a desire to spend holidays in nature, surrounded by silence in the middle of nature. Serbia has such regions and we should invest in them to make them competitive and to increase the number of tourists. This way the economic situation is improving, the population is being employed, agricultural products are used, etc." (Marinoski et al., 2014, p. 21). One of the measures is vouchers released by the government and given to a certain number of citizens, which have greatly increased the interest of citizens to travel within the borders of their country. Even before the Covid-19 pandemic and the state of emergency, originally planned 100,000 vouchers plus 60,000 additional were distributed in record time, during January and February. In the new situation, according to the demands and wishes of citizens, but also to motivate people to stay in their country and thus be responsible for their health and their families, the Ministry of Trade, Tourism and Telecommunications has released another 400,000 vouchers, which 
will cover a significant part of losses due to the cessation of business in tourism. Conditions for obtaining these funds have been simplified, so that students and people with incomes of up to 70,000 RSD can now apply for vouchers for accommodation in Belgrade and Novi Sad, whose offer had not been included before because these cities have otherwise realized a large number of overnight stays. Spas and mountains had the upper hand, and in the new circumstances, it is necessary to enable all parts of the country to earn money and attract tourists.

According to estimates, in the first five months of 2020, Serbia suffered damage of around 300 million euros due to lower foreign exchange inflows from foreign tourists, not counting domestic tourist trips. The damage based on the foreign exchange inflow this year will be close to a billion euros. Last year, tourism earned 1.4 billion euros, and 3.6 million tourists visited the country, an increase of eight percent. During the first two months of 2020, 453,728 tourists stayed in Serbia, a total of 1.4 million overnight stays were realized, and most guests from abroad were from Romania, Montenegro, Russia, Bosnia, and Herzegovina, and North Macedonia, according to which it could be concluded that one of the most successful years in tourism awaited us, which was abruptly and irreparably interrupted in March with a coronavirus epidemic and a state of emergency.

In order to determine how to use such circumstances for sustainable purposes and how to ensure the greater interest of domestic tourists in domestic destinations in the coming years, hoping without health problems, it is necessary to create campaigns that will not be based only on fear of disease, but rather on the desire to get acquainted with the rich tourist offer of own country, which often turns out to be less known than certain foreign countries. Also, it should be pointed out that it can contribute to the progress of other industries and the survival of many rural family households, because revenues from this type of tourism do not flow only into the state budget, but can enable the development and maintenance of small farms, that can provide tourist accommodation services. At the same time, people should be encouraged to pay attention to the offer of small farms, which, although it does not include luxury and modern trends, offers a different type of relaxation, in harmony with nature, and often reveals sites that are completely unknown to the general public. "Rural areas can offer special landscapes of exceptional value, ecological oases, fortresses of traditional culture, and ethno-cultural diversity heritage. Tourism is one of the activities that can have a significant impact on the economic, social, functional and physiognomic structure of the rural area" (Todorović, Bjeljac, 2007, p. 136).

The year 2020 is considered by forecasts, as well as certain reports, a year of rural tourism, and people engaged in this sector need help and support to properly prepare because the number and demands of tourists will be higher than ever before. Also, this opens opportunities for rural tourism to include households previously not involved in this activity, which will expand the offer. Of course, they will have to do certain preparatory activities to get involved in this business sector. In the first place, this includes certification of accommodation facilities and a description of everything that can be included in the tourist offer. In order to adequately do it, it is necessary to provide quality information and education to household members, so that they can recognize what to offer to the guests, and it is up to the authorities to assess the extent to which it can be interesting for tourists and what to do to enrich and adjust the offer according to demand. "Therefore, there is the need for law regulation in this area and precise definition of accommodation standards. World trends indicate that rural tourism is an ever-growing concept with increasing refined needs of domestic and international demand" (Vukosav et al., 2018, p. 770). Another idea is to expand the subsidies allocated for non-agricultural production to rural households 
and design new ones, which could help agricultural producers as a kind of additional activity. Serbia is still primarily a rural country, one of the few in Europe that has preserved the tradition of the rural lifestyle, households, field activities, as well as specific male and female chores, which can be presented to guests and encourage them to participate. "Rural tourism is one of the specifics of the tourist offer of Serbia, and its subtype - active rural tourism, which involves the participation of guests in household activities, fieldwork, gardens, vineyards, facilities for accommodation of people and animals, care of animals, preparation of food - is becoming more and more represented" (Radanov, Brzaković, 2017, p. 582). Even though it sounds possible in theory, in reality, is quite different. "Despite the wealth of natural and cultural resources, rural areas continue to suffer from high rates of unemployment, depopulation, low economic activity and decreasing natural resources "(Erdeji et al., 2013, p. 310).

For such a program, it is necessary to make a planning structure at the highest level, and then institutionally focus on local authorities and municipal tourist organizations, which have data on resources and potentials of their home areas, as well as opportunities for cooperation of nearby territories. Serbia has huge tourist resources thanks to its natural beauties, as well as cultural and historical heritage, which should be presented to the domestic traveler in a modern way and persuade him to come to know new parts of his country. "The importance of education can best be seen in the programs implemented within the protection of the population against AIDS and in the programs on traffic behavior. Such educations have saved many lives" (Radanov, 2016. p. 155). These examples show that the population in Serbia is ready to learn and be educated.

\section{RESEARCH}

\subsection{Assumptions that initiated the research}

In order to maintain interest in domestic tourist destinations in non-Covid conditions, not only during the pandemic of the dangerous virus, which ensures greater inflow of money into the state budget, encourage the preservation of values and wealth of our country and revitalization of abandoned and endangered areas, it is necessary to create a systematic approach, which will include both the wishes of tourists and the available capacity for the implementation of these activities. In this regard, it is necessary to adapt both: institutional measures must meet the needs of tourist workers, to modernize and present their offer, and on the other hand, tourists must show greater interest in domestic destinations. This precondition will be fulfilled if the tourist offer of Serbia is presented in the right way, that is, the requests of tourists get properly examined and if we provide conditions allowing them to realize their desires when it comes to vacation.

With a quick reaction, authorities started designing propaganda activities, to present the wider range of destinations, which will attract all categories of travelers. It is noticeable in previous years that when it comes to the use of vouchers, the most popular is spa tourism and the absolute record holds Sokobanja, which shows that tourists are not looking for luxury but natural and rare beauty, as well as the possibility of combining several types of tourism (health, rural, active, cultural-historical). In this area, guests can use health services in specialized centers, enjoy many picnic areas in the immediate vicinity, engage in various forms of recreation (swimming pool, sports fields, hiking), gastronomic offer is extremely rich, the segment of entertainment and relaxation is highly developed. Also, in this way, it is possible to satisfy the interests of different generations, so Sokobanja and its surroundings can be a good benchmark for creating 
the concept of a sustainable program for domestic tourists, as well as an indicator of specific expectations to be met in other areas to attract guests and position themselves better and more convincingly on the tourist map of Serbia. There are several localities in all parts of Serbia that can function in the same way as the Sokobanja region, even more successfully, it is only necessary to promote capacities and direct the actions of municipal authorities and local tourist organizations, with advisors from higher bodies and experts.

Practice shows that numerous guests use this type of travel and stay in the rural household to provide themselves with vegetable canning, which can be a significant source of income for the household. If this type of agreement is established, i.e. the guest, regardless of the stay, continues to be supplied with groceries and household products at least once a year or more often, and even recommends them to his acquaintances and friends, the household can count on a steady income and accordingly plan production and activities. It should be noted that the focus is primarily on small agricultural producers, who independently place and distribute their products on the market, mainly through local markets, buyers, and shops. Supporting a small producer, thus enabling it to move to the middle and develop its capacities, is the best way to reach a stable system, which will be able to expand in more directions and increase the number of employees and more diverse activities, as well as to include all family members, all ages and generations in the activities, which is of particularly important for maintaining the business. Also, the association of households and a unique offer and performance in a certain area increase the chances of successful business, because visitors have a greater range of activities and a much larger offer in all segments. In this way, it encourages staying in the countryside, supports agricultural production, and connects with other activities, in which a sustainable business is built in synergy, with the potential for progress and expansion.

It is necessary to provide additional incentives to small agricultural producers and encourage them with subsidies and education to get involved in tourism, to connect their main activity with tourism so that in cooperation with tourist organizations and representatives of municipal authorities for tourism and agriculture create activities that can involve guests (for example vegetable canning preparation). Also, this type of tourism can be educational, because guests can be trained, for example, to start beekeeping, to prepare traditional dishes, to make soaps or other home-made products, acquire the basics of some crafts, which expands the circle of experts and ensures preservation and expansion of these activities.

One of the specifics of the countryside life is the division into male and female jobs, which can be very interesting for a potential tourist. Women association in a joint promotion can significantly contribute to advertising and presentation of the area, and thus to attract a larger number of guests. Not negligible is the possibility for guests to help the hosts in certain activities, which will reduce the need to hire additional labor. This concept is based on the idea that people from the urban environment, which is becoming dominant in Serbia, increasingly want to be reminded of some activities from rural areas. It can also be a good incentive for those who have neglected properties to rent them, which would encourage the revival of the rural areas, or give them to use to socially endangered families. All this can be achieved through various initiatives and eco-initiatives because today's media and social networks enable information to be transmitted quickly and realistically. Thus, tourism and agriculture, i.e. micro-agriculture, would influence and encourage each other. This kind of tourist market is expanding very quickly through recommendations. They can also ensure the survival of one household and encourage others to turn to similar activities. 
Televisions have started broadcasting propaganda shows and reports about destinations in Serbia, to a much greater extent than before. Particularly important promotional channels are social networks, which are today the main and the fastest source of information and the most influential one because they transmit information in real-time and directly reach the targets. There is as well personal recommendation, known to be the strongest marketing tool, regardless of all modern theories. More individuals and agencies deal exclusively with domestic destinations, and to include the widest possible population in domestic tourism and find undiscovered areas in the current tourist offer, take into account all kinds of travelers, interweaving them and researching the market, which shows that they have systematically started designing campaigns. If there is no adequate accommodation in a certain area that has other potentials, it is necessary to work on engaging the local population that can be included in the rural tourism program.

However, the first border openings, after the emergency state ended, showed that people, despite warnings, always choose sea destinations as their first choice, which means that it is essential to influence the change of consciousness of our citizens to change their habits. That is why it is necessary to know which of their needs need to be met and to find out what is the key factor that determines them in choosing a destination and how to meet their requirements.

In the last few decades, the urban environment has begun to dominate the rural one, so that today's young generations are no longer able, like their parents, to spend their holidays in the countryside, because those villages are now often abandoned. Also, dramatic situations and the war in the former Yugoslavia caused a large number of people to lose a village to go to and thus take a break from the urban environment, which is now the only one identified with the quality of life and opportunities for good earnings. Therefore, potentially interested consumers exist, and a return to an authentic Serbian household and physical activities on it would be a real challenge for guests.

Given the presented opportunities, it was considered justified to conduct research on the interests and requirements of domestic tourists when it comes to domestic tourist destinations, to obtain data on how to keep this interest live in the future after the pandemic ends. It is useful to promote tourist destinations in Serbia, not only because of the economy but also because of getting to know the country of origin and the rehabilitation of some abandoned and historically and biologically valuable resources. Also, this could influence the determination of families to stay in smaller areas and engage in agriculture and to encourage individuals without employment to turn to agricultural and tourist activity.

It was essential to start the research with tourists, first to check what their interests are, and then conduct a survey among existing small farmers and property owners that can be used for these purposes, if not by the owners themselves then by other stakeholders (lease or assignment for use).

Following the recommendations on preventing the spread of the epidemic, the research was conducted safely, through an online Google questionnaire, using a "research instrument called the survey" (Havelka et al., 2004, p. 97).

\subsection{Hypothesis}

Analytical consideration of the situation in this area imposes three hypotheses:

$\mathbf{H}_{1}$ : The tourist offer adjusted to the requirements of travelers will attract domestic tourists who will remain regular guests. 
$\mathbf{H}_{2}$ : By including the tourist offer in their activities, small agricultural producers can improve their activity.

$\mathbf{H}_{1}$ : Providing institutional support to rural tourism enables the revitalization of forgotten and abandoned areas.

\subsection{Plan and research methods}

The survey was conducted online, via a Google questionnaire. This modern means of interrogation is increasingly used in public opinion research, and it is very practical to use because it can be distributed to a large number of respondents in a very short time. Also, since the questions are answered anonymously, the respondents give honest and thoughtful answers, which greatly affects the quality of the research. The questions were conceived clearly and unambiguously, and the answers were based on rounding off the offered options and adding personal views. The survey was distributed through personal channels, through associates, students, friends, and the social networks Facebook, Instagram, Twitter served as an additional channel for dissemination, with an explanation of the importance of providing this information. As many people are present on the networks, the response was higher than expected, so 375 completed survey forms arrived, which was enough to form a scientifically based opinion. The goal was to find an answer on how to ensure that interest in domestic tourist destinations is constant even when conditions are created for mass travel abroad, and on the other hand how small farms can be included in the sphere of active rural tourism.

\subsection{Research parameters}

The research sets parameters that in the given circumstances were directly related to the current situation due to epidemiological situation, but which in normal conditions can also be applied and used to improve the domestic tourist offer and divert the interest of domestic tourists to their own country, not only because of the security but also for several reasons.

Observed parameters: wishes and expectations of domestic tourists; quality presentation of the new and original offer on the tourist map of Serbia; selection of places that satisfy the desires of several generations; inclusion of small farms in the offer of rural tourism; contribution to the revitalization of certain parts of the country.

\subsection{Interpretation of parameters}

Wishes and expectations of domestic tourists. When making any strategy, one should first consider the wishes and possibilities of the average Serbian tourist. Some of its basic characteristics are modest purchasing power, one trip a year, often similar, which means security and controlled spending of the budget. It is necessary to examine what are the possibilities to change this standard picture, to point out that there is an option of favorable arrangements in Serbia, several times a year, which gives a new dimension to vacation and provides greater opportunities for quality relaxation. In domestic tourism, there is an option of weekend travels, because all destinations are relatively close, so with a good concept, people can enjoy getting to know different parts of Serbia for a small amount of money, through dynamically organized trips by an agency or independently. Most passengers expect good infrastructure, quality roads to the chosen location, but it should also meet the needs of tourists who want more alternative modes of transport to less accessible areas, to get acquainted with some hidden and rare natural beauties. Public opinion 
can be influenced by well-conceived campaigns and the benefits of local travels. Desires and expectations are observed by age groups because each generation has its habits and needs that need to be met, so it is necessary to have programs for all generations. In general, it is necessary to direct the aspiration to stay in a natural, healthy environment, while fulfilling all conditions of safety and security, which is quite important to today's tourists, due to the growing number of inconveniences that occur in the modern world and cannot be influenced.

Quality presentation of the new and original offer on the tourist map of Serbia. Quality and authentic presentation of the tourist offer is extremely important for attracting the attention of a potential traveler, and then for his final decision and choice. New marketing concepts show that personal impressions and emotions have the strongest influence on consumers, which means that marketeers should start creating promotional videos about the places to visit and what can be experienced there. In this regard, social networks can be crucial, because through them information is transmitted very quickly, comes firsthand, and represents an authentic and realistic testimony about activities guests can expect; they get a realistic picture of the landscape, accommodation, infrastructure. Today, reports of hobby travelers, who present their travels on the Internet, are very influential, often to some parts of Serbia that are unknown to most, which arouses interest and desire to see something new and different, which is very important for some tourists. Presentations should also include the offer of rural households to make it easier for users to decide when choosing. It is noticeable that in addition to several attempts, there is no single base of accommodation in rural households in Serbia, and it would also significantly help to set up maps on how to get to certain facilities, which is much easier with modern techniques and maps. However, in addition to individual initiatives of sincere nature lovers and treasures of Serbia, not much has been done at the institutional and comprehensive level. There are travel agencies that have profiled themselves only for destinations in Serbia, but they are still few and insufficiently influential. In addition to the already existing and known areas, it is necessary to promote some lesser-known localities that deserve attention and remain in the shadows. Maybe now is the right opportunity to discover rarities in Serbia, which will bring back love and emotion towards one's country.

Choice of places that satisfy the desires of several generations. The largest number of travelers choose the seaside and those are families who like this type of comfortable vacation with planned daily activities and a steady rhythm. Holidays are most often equated with relaxation on the beach and long walks, which can also be possible in domestic localities because we have rivers and lakes with an exceptional offer. Take for example the Đerdap gorge, lakes Vlasina, Srebrno, Zaovinsko, with excellent accommodation facilities, good access roads, and favorable prices. Besides, such places meet the requirements of several generations and different interests. For example, cities on the Danube, such as Kladovo, Golubac, Veliko Gradište, have exceptional beaches and promenades, bike paths, walking, recreational and hiking trails, there is the prehistoric site Lepenski Vir, traces of Roman times, Golubac Fortress, and other cultural and historical and natural specifics, which take at least a week to get to know completely, and all generations can find an activity that will suit their desires, affinities, and abilities. The local tourist offer can be crucially important, so the local tourist organizations should make additional effort to present the peculiarities of their region and to provide them with greater support in the promotion. It is expected that the tourist organization, local government, and owners of rural households in a certain area will work together, following a designed developmental and sustainable strategy of the area. This means that in addition to accommodation in the household, the special features and attractions of the immediate surroundings will be nicely integrated, to make the offer more interesting and suitable to several generations. The tourist organizations 
of smaller places in Serbia are neglected, even though they have a rich tourist potential, which if used properly can contribute to the overall progress of one area, and consequently to the creation of new jobs, the offer of new services, and thus the emergence of new sources of income.

Inclusion of small farms in the offer of rural tourism. The first movements of tourists after the mitigation of epidemiological measures showed that the known destinations are filled very quickly, which creates opportunities for opening new accommodation capacities. Statistics show that there is great interest in undiscovered areas and lesser-known landscapes, whit peace, and pure nature. In such circumstances, possibilities open for small farmers, who can offer accommodation services, located in a region of distinct natural beauty, where guests in addition to excursions and sports activities can be involved in household activities. Also, guests can be buyers of domestic products, thus contributing to the household economy, and spread the word about them, which will enable households to survive and indirectly affect the quality of life of the whole region. It is necessary to target and in the right way inform and include in the training members of households that can provide these types of services. Sometimes motivation is needed in the form of support and strengthening of self-confidence to enter this type of business, while in other cases financial incentives will be extremely important, most often subsidies for furnishing a house or auxiliary premise. It is an ideal circumstance in which several households in one area decide to enter this activity at the same time, because united and with mutual support, they can act easier and safer.

Contribution to the revival of certain parts of Serbia. By examining the characteristics of individual areas, it is possible to determine where it is possible to significantly influence the revival of devastated areas by encouraging rural tourism in areas that are dying out, already devastated, or with rapid emigrations. It is possible to design incentives at the state level, which would encourage landowners to return to these areas and start a business, or to sell them, or put them to lease for a certain period. Given the dynamic city life that includes an increasing degree of stress, there is a tendency to return to the countryside and consider options for buying property and putting it into business, whether within the tourist offer, or for agriculture, and it is possible to unite these options and thus obtain a sustainable strategy. There are many abandoned houses with orchards, backyards, meadows, which can be with valid investments turned into good production and tourist potential, and especially important is the option to consider growing organic food, which is a very profitable business, and in an area not used for a long time for these purposes; a certificate that the land is untreated, i.e. organic, can be quickly obtained. Positive examples of this kind would quickly influence other people to take the same business steps, which could lead to the revival of the entire village (a shiny example is the village of Vrmdža in eastern Serbia). The proposed sites can be areas of exceptional natural beauty: Vlasina, Jerma canyon, then numerous villages in the Raška area, where there is infrastructure, and thus provided accessibility, which is the main prerequisite for the revitalization of villages.

\subsection{Survey}

The survey included different age categories of respondents since the function of the research is to encourage all generations to recognize the benefits of domestic tourism, especially rural ones. Accordingly, different answers were recorded, which can help determine the interests and expectations of each group individually, and accordingly plan offers that will satisfy families with small children, and retirees, nature lovers, sports, young people who want to have fun and entertain. 
The questionnaire included the following questions:

1. Have you planned a trip this year? If so - where?

2. To what extent is your choice conditioned by the current epidemiological situation in the country and the world?

3. How often do you visit tourist destinations in Serbia?

4. Based on what do you choose destinations in Serbia?

5 . Which destinations are your most common choice?

6. How long do you stay?

7. Do you like to be stationed in one place or to explore the environment?

8. Are you interested in rural tourism?

9. Have you already used this type of tourist offer?

10. What do you expect from rural tourism (descriptive)?

11. Would you return to the same household if you are satisfied with your stay?

12. Would you regularly buy groceries from a rural household?

\subsection{Responds analysis}

The answers to the questions were given by choosing one of the usual three (yes - not - partially) offered answers, but with each question, it was possible to add a personal opinion on the examined phenomenon, and some questions only required description and presentation personal attitudes.

Question one. The analysis of the first question revealed that $62 \%$ of respondents were planning a vacation/trip this year, while $17 \%$ were unsure. The percentage of planned trips might have been even higher if the epidemic had not started in the first quarter of 2020, which distracted many people from traveling. More than half of the respondents who decided to travel in 2020 chose the sea as their first desired destination (58\%), which is in line with the traditional choice of Serbian tourists.

Question two. The change in the decision and the reorientation to locations in Serbia, in $75 \%$ of the respondents who want to travel, is a consequence of the epidemiological situation in the country and the world. From the media, it could be seen that traveling abroad is risky, due to the difficult departure, return, and complications with the duration of quarantine, which influenced the decision not to leave their country. Thus, the change is motivated by objective reasons and shows that it is justified to conduct research of this kind to determine how to encourage domestic tourists to choose domestic destinations more often. It is clear that the big disadvantage is that Serbia is a land country, and the majority of the population identifies vacations with sea destinations, but with properly directed campaigns, it is possible to influence public opinion to dedicate more to domestic destinations, if not every year, maybe every two years.

Question three. Respondents in a relatively low percentage of $21 \%$ state that they regularly visit tourist destinations in Serbia at least once a year. These are most often excursions, one-day trips, or extended weekends. A large number of respondents, as many as $41 \%$, very rarely travel in their own country, except for excursions near the place where they live. This shows that the values of one's country are not appreciated enough, that one does not want to get to know it, and that its resources and beauties are underestimated. Also, there is no awareness of community, the understanding that staying in domestic tourist accommodation will help domestic tourist workers and indirectly affect the better overall standard of living in Serbia. 
Question four. Destinations are chosen based on popularity (20\%), recommendations from close people (25\%), presence in the media (17\%), and social networks $(38 \%)$. The answers showed the absolute dominance of social networks in promoting destinations, thanks to the photos and videos, along with authentic comments, and have a strong influence on the observer who easily decides to make a choice. This may be the key to the promotion of domestic tourist potentials because practice shows that when they are familiar with the existence of a locality, people consider traveling to that area, especially because they have a personal authentic recommendation, which reduces the possibility of mistakes when choosing. Especially since Serbian tourist doesn't have high purchasing power, so he has been assessing for a long time whether and to what extent the offer will be in line with the package of services he will receive. It is often suspected that due to the lower price of accommodation in rural tourism, living conditions will not be good enough, although in practice it often turns out the opposite, because small businesses try hard to satisfy the guest, respect him more and take care of his needs, adjusting to his requirements to retain visitors.

Question five. Among the destinations in Serbia that are the most common choice of respondents are: spas (28\%), mountains (22\%), lakes (15\%), while in other percentages of about $10 \%$ in the answers are cities, culturally and historically significant sites, tourist events (one-day or multi-day). The answers confirm that the population of Serbia does not travel enough in their country. Staying in spas is mostly reserved for the elderly population and families with small children, travelers opt mainly for a safe choice of famous spa centers, while other, also very nicely decorated centers, remain little-visited, due to insufficient promotion and slow change of awareness of domestic travelers. It is necessary to research and discover the entire offer of domestic tourism.

Question six. When it comes to the length of stay, a high percentage (32\%) of respondents said that they usually spend three days at domestic tourist locations, an extended weekend for example, and much less often 7 or 10 days (15\%) for rest, while a tour of natural and historical sites is reserved for day trips ( $35 \%$ of respondents), either independently or organized through travel agencies. It would be important to extend the number of days that passengers spend in accommodation to the standard 10 days, which is usually spent at sea. Vouchers have significantly contributed to extending this period. On the other hand, in addition to the financial incentive, the package of activities that will be offered will be important, which will influence the guest to stay in one place for several days, in order to visit all the localities, experience various activities. The seventh question supports this analysis, as it is to be seen.

Question seven. Respondents of all ages in a high percentage (71\%) state that they like to explore the environment, that is, to get to know the area they came to. Therefore, in domestic tourism, static vacation is not a solution, but an active one, which includes relaxation activities, but also research walks, hiking tours, sightseeing, possibly attending local tourist events, participation in household activities, and the like.

Question eight. A 55\% of respondents said they were interested in rural tourism, which is an important fact because it shows that more than half of the population is ready to spend their holidays in a rural area. This sends a message to the government and local authorities to support rural tourism programs because in this niche is a significant resource not only for tourism but also for the revitalization of entire areas that have simply ceased to be important with modern industrial development, which led to extinguishing households and even entire villages. Discovering such areas and returning them to their purpose or discovering a new purpose can have a far-reaching impact 
on the recovery of the rural environment in some parts of Serbia and an opportunity for many people who want to return to nature and engage in tourism and agriculture to realize their plans.

Question nine. Rural tourism was used as a type of tourist service by $25 \%$ of respondents, and it is noticeable that families with small children, as well as slightly older people, opt for this type of vacation to a greater extent. This answer shows that more work is needed to promote rural tourism, for more people to choose this type of vacation, especially given the rich offer. Rural tourism should not be tied only to a static stay, because it also provides numerous opportunities for great fun for younger people, who love nature, adventure trips, walks, exploring the surroundings on foot or by bike, as well as other possibilities.

Question ten. Asked to describe their expectations from rural tourism, which relate to both accommodation and other characteristics of this type of tourist arrangement, respondents say they do not expect luxury accommodation, but a standard type of accommodation within a rural household, with basic benefits (cleanliness, bathrooms, accessibility of the location). Other expectations they state are peaceful vacation, stay in nature, participation in household activities at home and on the property as if they were in their village, the opportunity to get healthy food, learn something new, get to know parts of their country. A large number of respondents state that they especially appreciate the hospitality of the host because the feeling of intimacy and closeness is very important for a domestic traveler to feel nice and comfortable in the chosen accommodation.

Question eleven. A high 35\% of respondents say they would return to the same household, even more than once a year. This points out the psychological characteristic that the traveler usually chooses a safe vacation, which will certainly meet expectations, and when it comes to the village there is a personal connection because a large number of people were left without the opportunity to spend time in the countryside because of the lifestyle changes, migration, urban domination, so this is an opportunity to make up for this shortcoming. The percentage of respondents who prefer to always opt for new and unknown destinations is lower - $17 \%$, and among them are most often younger categories of people who are eager to discover new things and research. Therefore, when designing the offer, one should keep in mind the different categories of passengers and focus on the target groups.

Question twelve. A very large percentage - 71\% said they would like to buy products from a rural household. In the minds of our consumers, the rural environment is associated with health, unpolluted soil, and air, so they are ready to establish permanent cooperation with rural households from which to procure food such as cheese, dried meat, fruits, vegetables, various canning vegetables and fruits (jams, sweets, juices) and the like. Respondents rate this contact as a great advantage, especially those who do not have relatives in the countryside from whom they could procure such quality and healthy food. There is a large market for these products, and thus the opportunity for households to earn and in which direction to plan production for the coming seasons.

\subsection{Proving hypotheses}

\section{1) The tourist offer adjusted to the requirements of travelers will attract domestic tourists who will remain regular guests.}

The survey showed that domestic tourists are interested in touring their country, as well as in accommodation in rural households, which provide a very high-quality service at affordable prices 
and a whole range of activities that guests can do. A large percentage of domestic tourists do not expect luxury and comfort, but basic amenities, and they give priority to the attractiveness of the locality and the possibility for people of several generations to enjoy. They are interested in local products, local events and it is necessary to have more information about rural areas in the public, as well as photos from these areas. The influence of social networks is nowadays the biggest marketing tool because the presence on networks is measured by millions of users who are active every day. Statistics show that the largest number of recommendations come through social networks, which means that personal impression is the best recommendation and advertisement. Photos are crucially significant here, as well as video clips because they show an accurate picture and influence the recipient, encouraging his desire to have the same experience.

Structural analysis of the potential of an area and the wishes of tourists can quickly lead to conclusions about which areas can be improved and what needs to be added to the existing offer. It is also important to select the target groups for which the offer of a specific area will be intended, to adjust the existing capacities with the smallest possible investments and for the shortest possible period. For example, adapting the offer of the spa to young people or children will require much more work and investment, but expanding to slightly younger categories will be possible in a very short time, with regular visitors and companions, knowing that they will have many activities and a wide range of diverse tourist offer.

\section{2) By including the tourist offer in their activities, small agricultural producers can improve their activity.}

Such attitudes confirm that in Serbia there are great prospects for engaging in rural tourism, especially for households that are already engaged in agriculture and have the conditions to include tourism in their activities. Earlier research has shown that the owners of rural households do not easily decide to enter the tourist business because they do not have the experience or enough information, so they do not dare, they do not have self-confidence. With adequate support from the local authorities and the tourist organization, families can easily and quickly get involved in this activity and adapt to new working conditions, so with good education they can be trained on what to do, how to treat guests, what to offer. With the new knowledge, they will gain the necessary self-confidence, perform more confidently on the market, and continue with the acquisition of skills.

There is an increasing number of travelers looking for rarities, hidden areas, yet undiscovered. It is all about the prerogatives of the new age in which we live, which puts information in front of us, so it quickly becomes saturated, and the individual needs to stand out and originally present himself so that when it comes to tourism, he will go to a location which is not much exploited. This characteristic of the modern man should be taken into account, no matter how negative it may be, and turn it in favor of an area with a smaller population, abandoned, sparsely populated, which for these reasons will be interesting to tourists who will see attractiveness, originality, a peculiarity about already known domestic destinations. The main problems when it comes to these destinations in Serbia are the roads and accessibility, but there are several possibilities how this can be overcome, and to also be included in the attractive tourist offer: driving SUVs, jeeps, trucks, etc.

In such conditions, rural households can offer activities such as a collection of medicinal herbs, healthy food, medicinal springs, localities with special air currents, along with historical and other localities, which can all build a very stable structure of tourist offer, with peace and relax- 
ation, which is especially needed by guests from the city, because there is an increasing number of tourists who want to spend a peaceful and relaxing holiday. Also, camping nearby can be encouraged if households do not have accommodation facilities, provide a good camping place, because now the offer of camping equipment is large and affordable, portable, and easy to install. In that case, households can focus on some other service offers. In this way, such areas get the much-needed support, information is transmitted through a direct recommendation and the number of guests increases relatively quickly, which encourages other residents to get involved in the same activity.

\section{3) Providing institutional support to rural tourism enables the revitalization of forgot- ten and abandoned areas.}

It is necessary to educate the owners of small households about everything necessary to get involved in the offer of rural tourism, through training, information material, to show them whether they meet the prerequisites for tourism and to show what they can use in the offer of their household. It is also possible to encourage more households to network, which makes business easier and provides a sense of security. This can be especially important in abandoned areas of great natural beauty and wealth. Accordingly, it is necessary to offer certain subsidies to support the existing capacities to adapt to the purpose.

There are numerous reports from Serbia showing abandoned areas, abandoned houses, backyards, orchards, unmown meadows, on the other hand, an increasing number of people and initiatives to return to the countryside, supporting people's decisions to leave work and life in the city and move to the countryside, for the sake of a healthier and more peaceful life. In this concept, the tourist offer can additionally contribute to the promotion of the area, influence decisions to make it easier for individuals to decide on such business and life moves because to a certain extent it guarantees that the invested funds will return. That is why more subsidies and incentives must be awarded through various competitions to individuals, associations, who want to start various activities in abandoned or impoverished areas of Serbia, which can be a significant economic injection for the whole region and generate new employment and expansion of activities.

\section{FUTURE RESEARCH DIRECTIONS}

An area such as tourism is an inexhaustible source of income, but only if resources are used wisely. On the other hand, it is necessary to keep up with the times and to adjust the offer to the demand, even when it is out of the comfort zone. Risk and embarking on something new are necessary if tourism is to be kept alive. The conducted research showed that there is interest in domestic tourist destinations, and even if it is mostly caused by Covid-19, it is still an opportunity for tourists to be attracted and stay for longer. On that road, the help of the state, the relevant ministry, local authorities, and tourist organizations is necessary. With that in mind, further research should in the first place determine which parts of Serbia could specifically engage in this business venture, keeping in mind the primarily neglected areas. It is then necessary to investigate in detail what kind of assistance is needed by potential destinations. Based on this knowledge, local authorities could plan the budget and the distribution of funds. Another important direction is market research, where it is necessary to investigate in detail what activities and contents today's tourists are looking for, to harmonize it with the offer of rural tourism. Also, research on this area should continue in another niche, among small agricultural producers, and examine the extent to which they are interested in getting involved in rural tourism because 
the market is large enough to accommodate more workers in this area. And finally, in the hope that all the above will be realized, a long-term research plan is to examine the results of such a venture after a few years.

\section{CONCLUSION}

The research conducted primarily in order to recognize the interest of domestic tourists for domestic destinations showed that the given situation can be redirected in favor of rural tourism, in which travelers are interested and which can make great progress. Therefore, we can say that in very bad circumstances, such as the pandemic of the dangerous virus, a useful possibility arose. Unable to travel abroad, and eager to change places, find relaxation, tourists have reoriented themselves to domestic destinations. As the main domestic tourist centers were preoccupied, and under the danger of infection, people were looking for more secluded and hidden places, small households that offer a safe and comfortable stay in pure nature came to the fore. Personal recommendation and social networks have again proved to be much more influential than large promotional campaigns of tourist organizations, which should be considered when forming future marketing strategies. Rural households provide comfort and peace that modern man needs, and with the future that seems to await us all, we will need this type of vacation several times a year, if possible. Establishing ties with the hosts opens the possibility for the purchase of food and other home-made products, which can be a significant boost to the economy of the household, and even the entire area. What is especially important, it provides an opportunity for the revitalization of abandoned and forgotten areas, which are in areas of exceptional natural beauty.

In order to start this activity, it is necessary to influence the consciousness of a domestic tourist, who is not used to traveling in his country, that is, he does not know it well enough. This claim is supported by the fact that a large number of people are surprised by certain destinations, which shows that they are not familiar with the natural rarities and cultural and historical features of their country. Confirmation for this can usually be found on social networks, which have become a real mirror of public opinion, but also a place where people can be positively influenced and through appropriate programs work on education and motivation to get to know their own country.

The research showed that rural tourism has great potential outside the summer tourist season, which is the main one, and that it is active all year round. To this end, cooperation with local authorities and tourist organizations must conceptualize plans for improving and expanding the offer. And when the conditions for that are met, that is, the epidemiological conditions improve and travel continues in full, the results will be even greater, with local tourist events and a larger scope of activities. Serbia is a country of great and insufficiently used beauties and resources that are endangered today, and by encouraging rural tourism, their preservation can be ensured, as well as the economic progress of the entire region and the benefit for the whole society.

\section{REFERENCES}

Brzaković, P., Lešević, I., \& Radanov, P. (2020). Turizam Srbije u uslovima epidemije: parkovi prirode i nacionalni parkovi kao potencijalne destinacije. International scientific conference The fourth industrial revolution - the importance for green economy Progress and environmental protection, Belgrade: Ecologica, 104-105.

Đorđević, S. (2016). Turistička animacija u funkciji razvoja ruralnog turizma u Srbiji. Turističko poslovanje, No. 18, 43-49. 
Erdeji, I., Gagić, S., Jovičić, A., Medić, S. (2013). Development of Rural Tourism in Serbia. Journal Settlements and Spatial Planning, Special issue, No. 2, 309-315

Havelka, N., Kuzmanović, B., \& Popadić, D. (2004). Metode i tehnike socijalnopsiholoških istraživanja. Beograd, Serbia: Centar za primenjenu psihologiju.

Lešević, I., Radanov, P., Brzaković, P., Tomić, G. \& Pajić, D. (2020). Uloga sredstava javnog informisanja u širenju informacija od opšteg značaja. Ecologica, N 99, 525-529.

Marinoski, N., Stamenković, P., Conić, P. (2014). Gastronomski sadržaji ruralnog turizma u Srbiji. BizInfo, year 5, No. 1, 19-36.

Medojević, J., Milosavljević, S., Punišić, M. (2011). Paradigms of Rural Tourism in Serbia in the Function of Village Revitalization, Human Geographies - Journal of Studies and Research in Human Geography, 5.2, 93-102.

Radanov, P., \& Brzaković, M. (2017). Healthy Life in the Function of Tourist Offers - Mentor Support, Modern management tools and economy of tourism sector in present era. Second international thematic monograph - Thematic proceedings (pp. 582 - 598). Belgrade: Association of Economists and Managers of the Balkans with Faculty of Tourism and Hospitality, Ohrid, North Macedonia.

Radanov, P. (2016). Research of awareness of South Banat residents about air, water, land and food pollution. Monograph Environmental awareness as a universal European Value (pp. 152-167). Bor: University of Belgrade, Technical Faculty in Bor.

Radović, G. (2020). Underdevelopment of Rural Tourism in Serbia: Causes, Consequences and Possible Directions of Development. Economics of Agriculture, year 67, N. 4, 1337-1352.

Spasić, V. (2013). Poslovanje turističkih agencija i organizatora putovanja. Beograd, Serbia: Univerzitet Singidunum.

Todorović M., \& Bjeljac, Ž. (2007). Osnove razvoja seoskog turizma u Srbiji. Bulletin of the Serbian geographical society Vol. LXXXVII, No. 1, 135-148,

Tomić, Z. (2003). Komunikologija. Beograd, Serbia, Serbia: Čigoja.

Tomka, D. (2012). Osnove turizma. Novi Sad, Serbia: Univerzitet Educons.

Vukosav, S., Garača, V., Bradić, M. (2018). Analyses of Regulations Regarding Accommodation Facilities Categorisation in Rural Tourism in Serbia. Economics of Agriculture, 65, No. 2, 769-786.

Čerović, S. (2002). Strategijski menadžment turističke privrede Srbije. Beograd, Serbia: Želind Press.

\section{ADDITIONAL READING}

Bakić, O. (2005). Marketing menadžment turističke destinacije. Beograd, Serbia: Univerzitet Singidunum.

Bartlet, T. (2006). Rural Tourism Development in Europa, International Forum on Rural Tourism, China-Final Report World Tourism Organization.

Bošković, T. (2009). Turizam kao faktor privrednog razvoja. Novi Sad, Serbia: Visoka poslovna škola strukovnih studija.

Genov, G. (2008). Turizam posebnih interesa - Selektivni oblici turizma. Beograd, Serbia: Čugura print.

Đorđević - Milošević, S., \& Milovanović, J. (2012). Održivi turizam u funkciji ruralnog razvoja. Beograd, Serbia: Univerzitet Singidunum.

Selaković, D. (2014). Ruralni turizam - između teorije i prakse. Beograd, Serbia: Srpsko geografsko društvo. 